\title{
An Employer's Recourse to Lock-Out and Replacement Labour: An Evaluation of Recent Case Law
}

MM Botha* and M Lephoto**

\section{P.E.R}

Pioneer in peer-reviewed, open access online law publications

Author

Monray Marsellus Botha

Motsoane Lephoto

Affiliations

University of Pretoria

North-West University

South Africa

Email

monray.botha @up.ac.za

lephoto44@gmail.com

Date published

7 December 2017

Editor Prof AA du Plessis

How to cite this article

Botha MM and Lephoto M " An

Employer's Recourse to Lock-Out and Replacement Labour: An

Evaluation of Recent Case Law" PER / PELJ 2017(20) - DOI

http://dx.doi.org/10.17159/17273781/2017/v20i0a1594

Copyright

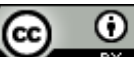

DOI

http://dx.doi.org/10.17159/1727-

3781/2017/v20i0a1594

\begin{abstract}
South African labour affairs are in a volatile state. Conflicting rights and interests as well as the balancing of these rights and interests are contributing to this state of affairs. In recent years, the contentious issues of workers' right to use their economic power to put pressure on employers and employers' recourse to lock-out and replacement labour have come under the spotlight again. Prolonged, violent and unprotected strikes have raised the question whether our industrial relations framework should be revisited, and have complicated matters even further. The question whether employers may use replacement labour and have recourse to lock-outs when an impasse exists during wage negotiations is considered in the context of the adversarial collective bargaining framework in South Africa.
\end{abstract}

\section{Keywords}

Collective bargaining; industrial relations; strikes, defensive and offensive lockouts; pickets; replacement (scab) labour. 


\section{Introduction}

The purpose of the Labour Relations Act $^{1}$ (LRA) is to advance economic development, social justice, labour peace and democratisation of the workplace. ${ }^{2}$ The primary objects of the LRA include the following: "[T]o provide a framework within which employees and their trade unions, employers and employer's organisations can (i) collectively bargain to determine wages, terms and conditions of employment, and other matters of mutual interest; and (ii) formulate industrial policy"3 and (iii) "to promote orderly collective bargaining [and] collective bargaining at sectoral level".4

The LRA in its purpose provision also provides for the advancement of the effective resolution of labour disputes. Central to collective bargaining is the right to strike and the recourse to lock-out available to employees and employers respectively. Workers exercise collective power primarily through the mechanism of strike action. On the other hand, employers may exercise power against workers "through a range of weapons, such as dismissal, the employment of alternative or replacement labour, the unilateral implementation of new terms and conditions of employment, and the exclusion of workers from the workplace (the last of these being generally called a 'lock-out')". ${ }^{5}$

It has been said that "South Africa faces deep problems of poverty, unemployment and inequality" 6 that these problems have a direct influence on participants in the labour relations environment, and that they shape the issues over which they engage and the manner in which they do so. ${ }^{7}$ Thus, the high rate of unemployment in South Africa makes it easy for employers to find a labour source when their employees participate in strike action. ${ }^{8}$

In South Africa the right of workers to strike is constitutionally enshrined. Section 23 of the Constitution of the Republic of South Africa, 1996 (the

\footnotetext{
* Monray Marsellus Botha. BLC LLB LLM BCom (Hons) (Pret), MCom (UJ), LLD (NWU), Advanced Diploma in Insolvency and Practice (AIPSA) (Pret), Advanced Diploma in Corporate Law (UJ), Advanced Diploma in Alternative Dispute Resolution (AFSA/Pret). Head of Department of Mercantile Law, Faculty of Law, University of Pretoria. E-mail: monray.botha @up.ac.za.

** Motsoane Lephoto. LLB, LLM (NWU). LLD Candidate, North-West University. Email: lephoto44@gmail.com

Labour Relations Act 66 of 1995 (LRA).

Section 1 of the LRA.

Section 1(c)(i)-(ii) of the LRA.

Section 1 (d) (i)-(ii) of the LRA.

See In re Certification of the Constitution of the Republic of South Africa, 19961996

4 SA 744 (CC) (hereafter Certification case) para 66.

Anstey 2013 SAJLR 141.

Anstey 2013 SAJLR 141.

Van der Welden and Dribbusch Strikes Around the World 54.
} 
Constitution) unequivocally states that every worker has this right. Also, this right is given effect to in section 64 of the LRA. In many countries, including South Africa, the struggle for the right to strike has been a long and painful one for trade unions and workers. Historically, in South Africa striking constituted a criminal offence and the common law did not recognise the right to strike. For example, the Railway Regulation Act of 1908 denied railway employees the right to strike under penalty of criminal prosecution. Also, under the Labour Relations Act 28 of 1956 (the 1956 LRA), strikes and lock-outs were illegal under certain circumstances. ${ }^{9}$ At common law, strike action constituted a fundamental breach of contract which entitled the employer to dismiss striking employees. ${ }^{10}$ It is therefore not surprising that the Constitutional Court has noted that the right to strike "is both of historical and contemporaneous significance". ${ }^{11}$

In essence, collective bargaining is about the balancing of power so that employers and employees are able to utilise their respective labour weapons (that is, the use of replacement labour or recourse to lock-out by the employer and employees' right to strike). The LRA is also concerned with possible power imbalances, as it creates the respective rights and recourses that enable the parties to use their economic powers against each other once the matter in dispute has been unsuccessfully referred to conciliation Previously it was said that the relationship between collective bargaining and industrial action:

$\ldots$ is much like the relationship between diplomacy and war [as] it is the threat of force and the pain which its exercise might inflict on either side which generally induces governments to seek solutions to international problems by negotiation. The threat of superior force also governs the way statesmen move their pieces in the bargaining game. This may entail bluff which, in the final analysis, can only be called by declaring open war. But even after war breaks out, diplomacy continues, unless the more powerful side demands unconditional surrender.

However, it is unwise to push the analogy between warfare and strike action too far. Strikes are not battles fought in a constant war between management and labour; they are merely the means by which employees periodically exert their collective right to withdraw labour, and by which management's liability to do without labour is weighed against the workers' capacity to endure without pay. To equate strike action with warfare may lead to misconceptions, not the least of which is to regard strikes as a justification for drawing other 'weapons' to induce surrender. Strikes may often deteriorate into mob action, which the courts will interdict. Similarly, however, employers are tempted to regard dismissal as their 'ultimate weapon', a tendency corrected by the Supreme

$9 \quad$ See s 12(1) of the Labour Relations Act 28 of 1956 (the 1956 LRA).

10 See Myburgh 2004 ILJ 962; Grogan Collective Labour Law 141; SACWU v Afrox 199920 ILJ 1718 (LC) para 19.

$11 \quad$ NUMSA v Bader Bop 200324 ILJ 305 (CC) para 13. 
Court of Appeal in Betha \& others v BTR Sarmcol (a division of BTR Dunlop $L t d)^{12} \ldots$

The above thoughts notwithstanding, it is difficult to resist comparing strikes and lock-outs with warfare because they both entail the use of collective power to force the other party to do what they do not wish to do. Strikes are calculated to cause harm, not only to the employer, but also to non-striking employees and even customers and suppliers. But strikes are not a licence to cause physical harm. This is why in most common-law jurisdictions courts have been reluctant to acknowledge a right to strike. As been pointed out, no other basic human right exists for the sole purpose of forcing others to do what they do not wish to do. The theoretical basis for such a right is its pivotal role in the exercise of another right - namely, the right to collective bargaining. ${ }^{13}$

Collective bargaining has a long history, as is evidenced by the developments in various countries. ${ }^{14}$ It has also played an important role in granting workers a "voice" in organisations. Collective bargaining is an adversarial process, which involves negotiation between parties with conflicting interests "seeking to achieve mutually acceptable compromises". ${ }^{15}$ For workers it is primarily ${ }^{16}$ a means of maintaining "certain standards of distribution of work, of rewards and of stability of employment", while employers view it as a means of maintaining "industrial peace". ${ }^{17}$ Since 2007 the adversarial nature of collective bargaining has become increasingly evident due to "a decline in negotiating capacity, the reemergence of non-workplace issues negotiations, and the rise of general mistrust between the parties". ${ }^{18}$ These are also the key factors that contribute to the worsening of the collective bargaining process. ${ }^{19}$ Botha points out that "[t]he focus on strikes, have [sic] unfortunately, not been positive, as some industries have been plagued by violent, and/or unprotected and sometimes protected strike action that carries on for long periods of time". 20

According to Levy, an examination of the data on industrial action in South Africa over the last decade "shows an emerging pattern of great concern, reaching a point where it must be seen as a question of the utmost national

Betha v BTR Sarmcol (a Division of BTR Dunlop Ltd) 199819 ILJ 459 (SCA). References omitted.

Grogan Collective Labour Law 191-192.

Du Toit 2007 ILJ 1405.

Godfrey et al Collective Bargaining 1.

Du Toit 2007 ILJ 1405 points out that the "qualifier 'primarily' is important: power built up in the bargaining arena enables trade unions also to engage with broader issues and exert political pressure".

See Davies and Freedland Kahn-Freund's Labour and the Law 69; as well as Godfrey et al Collective Bargaining 1; Du Toit 2007 ILJ 1405.

National Planning Commission 2012 para 34.

Benjamin 2014 ILJ 1-3.

Botha 2015 Obiter 194. 
importance". ${ }^{21}$ The data shows that the incidence of strikes declined from 1995 until about 2003, when it began to increase. More worryingly, the data also shows that from 1995 to 2012 there has been an increase in the number of strikes that last for longer than a month. This has led to the conclusion that "we can expect strikes to become longer in the future".22 Indeed, the 2014 statistics compiled by the Department of Labour showed that there were fewer strikes than in 2013 but that they were longer. ${ }^{23}$ It is important to note that $52 \%$ of strikes in 2014 were protected while $48 \%$ were unprotected. This was the direct opposite of what occurred in 2013 when $52 \%$ of strikes were unprotected while $48 \%$ were protected. ${ }^{24}$ More recently, among the 110 strikes which occurred in $2015,45 \%$ were protected while $55 \%$ were not. $^{25}$

On the other hand, employers are turning to replacement labour (also known as "scab labour") during industrial actions. In 2003 the use of scab labour was at $36 \%$, and it rose to $45 \%$ in 2004 before another increase took place, to $50 \%$ in 2005 . In $2010,40.9 \%$ of employers reported having used scab labour as against $27.5 \%$ in $2009 .{ }^{26}$

Two recent judgments addressing pertinent issues in relation to an employer's recourse to lock-out and the employment of replacement labour during a strike have put the spotlight back on the use of these labour weapons by employers. ${ }^{27}$ The two judgments, Transport and Allied Workers Union of South Africa $v$ Putco Limited ${ }^{28}$ and SACCAWU $v$ Sun International, ${ }^{29}$ form the basis of this discussion regarding the use of replacement labour during lock-outs.

Levy "Strike Action" 6.

Levy "Strike Action" 7-9.

Department of Labour Annual Industrial Action Report 20143.

Department of Labour Annual Industrial Action Report 2014 viii, 35.

Department of Labour Annual Industrial Action Report 201511.

Department of Labour Annual Industrial Action Report 2006 2; Department of Labour Annual Industrial Action Report 2010 vii.

27 It should be noted that employers' recourse to lock-out is not constitutionally enshrined like employees' right to strike, but the LRA recognises it as a legitimate weapon available to employers.

28 TAWUSA v Putco 20166 BLLR 537 (CC).

29 SACCAWU v Sun International 20161 BLLR 97 (LC) (hereafter Sun International case). 


\section{The Putco trilogy ${ }^{30}$}

\subsection{The facts}

This case involved two applications brought by the Transport and Allied Workers Union of South Africa (TAWUSA) on behalf of its members against Putco and another bus company, Algoa Bus Company. The two applications were heard together. Putco carries on business as a passenger bus operator and provides public passenger bus services. TAWUSA represented approximately $26 \%$ of the employees of Putco while the South African Transport and Allied Workers Union (SATAWU) and the Transport Omnibus Workers' Union (TOWU) represented approximately 46\% and $27 \%$ respectively.

Putco is a member of the Commuter Bus Employer's Organisation (COBEO), which is an employers' organisation member of the South African Rail Passenger Bargaining Council (SARPBAC). TAWUSA, SATAWU and TOWU were the employees' representatives at the SARPBAC. However, TAWUSA resigned from the SARPBAC sometime in August 2012. In 2013, wage negotiations at the SARPBAC deadlocked and SATAWU and TOWU gave notice that they would commence with a protected strike on 17 April 2013.

On 19 April 3013, Putco issued a notice of lock-out directed to the applicant, TAWUSA, in response to the notice to strike issued by SATAWU and TOWU. The notice of lock-out stated the intention to lock all affected employees out. It read as follows:
In response to the strike notice issued, the Company hereby gives 48 hours' notice of its intention to lock-out all employees in the bargaining unit from all of PUTCO Limited's workplaces in support of the employer wage proposals in the wage negotiations in the South African Road Passenger Bargaining Council. (Own emphasis.)

On the same day TAWUSA advised the employer that its members would not strike and would report for duty as normal. TAWUSA also advised the employer that any lock-out against its members would be unlawful. Aggrieved by the notice to lock its members out, TAWUSA approached the Labour Court on an urgent basis for an interdict. The Labour Court framed the issue to be determined as follows:

Crisply put, the question is whether an employer faced with a strike called by one or two unions can lawfully lockout all its employees inclusive of those not

$30 \quad$ TAWUSA obo members v Algoa Bus Company and Putco 201334 ILJ 2949 (LC) (hereafter Putco 1); Putco v TAWUSA 201536 ILJ 2048 (LAC) (hereafter Putco 2); and TAWUSA v Putco 20166 BLLR 537 (CC) (hereafter Putco 3). 
on strike, having not been called to strike by the union they belong to. ${ }^{31}$

\title{
2.2 Putco 1: The Labour Court judgment
}

The court began by noting that it was loath to entertain a debate regarding whether or not the lock-out in question was a defensive or offensive one. ${ }^{32}$ Relying on an earlier judgment of the Labour Appeal Court, ${ }^{33}$ the court made it clear that the main focus should be on whether the conduct which was under scrutiny - in this case the notice to lockout employees - was permissible in terms of the LRA. ${ }^{34}$ In order to answer this question, the court mainly focused on the definition of the term "lock-out" as enunciated in section 213 of the LRA, namely:

\begin{abstract}
the exclusion by the employer of employees from the employer's workplace, for the purposes of compelling the employee to accept a demand in respect of any matter of mutual interest between employer and employee, whether or not the employer breaches those employees' contracts of employment in the course of or for the purposes of their exclusion. ${ }^{35}$ (Own emphasis added.)
\end{abstract}

The court emphasised the fact that the definition contains the phrases "for the purpose of compelling the employee to accept a demand" and "those employees". To whom does the phrase "those employees" refer? In answering this question, the court held that the phrase refers to employees who have refused to accept a demand made by their employer. Put differently, the court held that a lock-out must be directed at employees with a demand. As the court explained, "logic dictates that one cannot compel somebody who does not resist or one who does not present a counterdemand". ${ }^{36}$ In similar vein, the court held that a lock-out must have a purpose; that is to say, when implementing a lock-out the purpose should be to compel those employees to accept a demand. This was so because, as the court reasoned, the exclusion of employees without any purpose is not a lock-out as defined and is bound to be unlawful in terms of the LRA. ${ }^{37}$

In addition to the above definition of the term "lock-out", the court also emphasised the fact that section 64 of the LRA - which provides for the right to strike by employees, recourse to lock-out by employers and the procedural requirements for protected strikes or lock-outs - refers to the word "dispute" several times. In the case of a proposed lock-out a notice must be given to a trade union which is a party to the dispute or, if there is

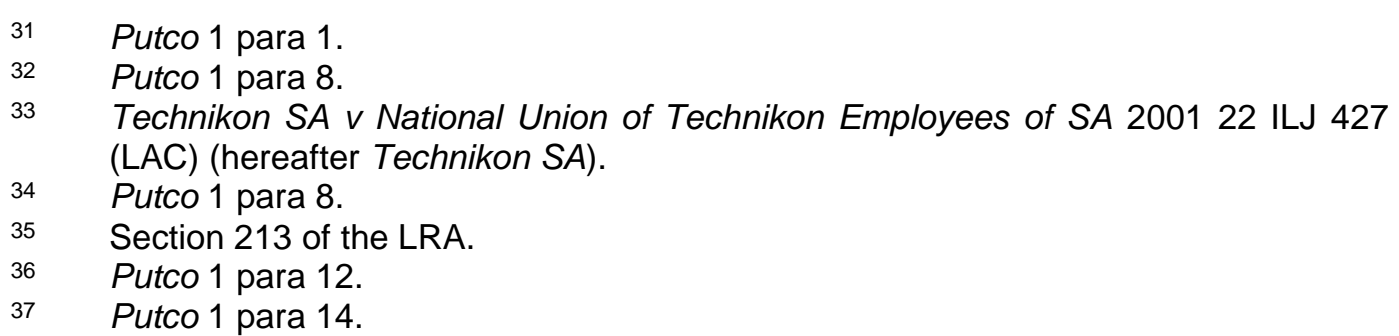


no trade union, to the employees. ${ }^{38}$ Based on this provision, the court held that the trade union which has to be given notice of the intended lock-out is one which is a party to the dispute. If a trade union is not a party to the dispute, so the court reasoned, it ought not to be notified of the proposed lock-out. ${ }^{39}$

It is important to note that there was a dispute on the papers on whether or not TAWUSA had said that it would support the strike called by SATAWU and TOWU. The court held that it had not. Also, the court determined that both employers (Putco and Algoa Bus Company) had not made any demand which had been rejected by TAWUSA and which would have constituted a dispute. 40

In applying the law to the above facts, the court held that the LRA does not allow a lock-out to be directed at all employees. ${ }^{41}$ Put differently, the court held that an employer faced with a strike by some of its employees may not lawfully lock out all of its employees, including those not on strike. The court granted an interdict against each of the two employers (Putco and Algoa Bus Company) from continuing to lock out TAWUSA's members in their employ. ${ }^{42}$

\subsection{Putco 2: The Labour Appeal Court judgment}

Not satisfied with the Labour Court's judgment, Putco appealed against it. Algoa Bus Company did not lodge an appeal against the Labour Court's judgment. The fact that collective bargaining on wages and other conditions of employment in the transport industry took place at the SARPBAC was the key factor in the court's determination of the appeal.

On appeal both sides raised virtually the same arguments as they had in the court aquo: TAWUSA argued that it was not a party to the dispute that had arisen at the SARPBAC, and since it had not declared any dispute with Putco the lock-out against TAWUSA members was unlawful. On the other hand, Putco argued that an employer who was party to a bargaining council should be entitled to lock out employees who are members of a non-party union because the non-party union members have a material interest in the outcome of the dispute. The lock-out, so the argument went, would promote collective bargaining at sectoral level and would give effect to the

Section 64(1)(c) of the LRA.

Putco 1 paras 15-16.

Putco 1 paras 19, 34, 35 and 42.

Putco1 para 19.

Putco 1 paras 43-46. 
majoritarian principle which underlies the collective bargaining dispensation in South Africa.

The court noted the fact that the constitution of the SARPBAC provided that all collective agreements concluded under the auspices of the SARPBAC were binding on all eligible employees in the employ of the employers' organisations and on those parties and or individuals to whom it was extended in terms of section 32 of the LRA. Therefore, the court held that TAWUSA's members had an interest in the negotiations at the SARPBAC (where SATAWU and TOWU had rejected the employer's wage demands) and that the dispute was about a matter of mutual interest to the employer and the employees. ${ }^{43} \mathrm{Also}$, the court held that the definition of a lock-out in the LRA does not provide that it should be directed at striking employees only. Therefore, so the court reasoned, an employer may lock out all employees (striking or non-striking) who do not accept the employer's demand. It is important to note that the court held that TAWUSA had expressly rejected the employer's wage demand. ${ }^{44}$

The court went on to explain that an employer, as part of its strategy to put pressure on its employees to accept its demands, may decide to lock out all employees in order to achieve an individual or group capitulation. ${ }^{45}$ The court further held that since the members of TAWUSA could decide to join the strike at any time without giving notice to the employer, it would be unfair to expect the employer not to implement a lock-out against them whilst they were refusing to accept the employer's demand. ${ }^{46}$

In the light of these findings, the court held that Putco had acted lawfully when it locked out the members of TAWUSA. ${ }^{47}$ The appeal was upheld and the order of the court a quo was set aside.

\subsection{Putco 3: The Constitutional Court judgment}

Dissatisfied with the Labour Appeal Court's judgment, TAWUSA appealed against it. In a unanimous judgment (per Khampepe J), the Constitutional Court framed the issue before it as follows:

The central question in this case is whether the Labour Relations Act (LRA) permits an employer to exclude from its workplaces, by way of a purported lock-out, members of a trade union that were not a party to a bargaining

$43 \quad$ Putco 2 para 62. Moreover, the court emphasised the fact that the members of TAWUSA would reap the benefits of the wage negotiations at the SARPBAC should the demands of the majority trade union be accepted.

$44 \quad$ Putco 2 para 67.

$45 \quad$ Putco 2 para 64.

$46 \quad$ Putco2 para 65.

$47 \quad$ Putco 2 para 70. 
council where a dispute arose and was subsequently referred for conciliation. ${ }^{48}$

TAWUSA argued that section 64(1)(c) envisages locking out a party who has an interest in a dispute, or who is directly affected by it. It further contended that section 64(1) does not authorise a lock-out against a trade union and its members who are not party to the dispute that has given rise to the lock-out. It emphasised that a lock-out is defined as the exclusion from the workplace by an employer of its employees for the purpose of compelling these employees to accept a demand. Consequently, so the argument went, there can be no dispute if there is no demand. On the facts of the case, it argued that there could not have been a demand made to it as it was not a member of the bargaining council where the dispute arose. On the other hand, Putco argued that section 64(1) of the LRA provides that notice to a bargaining council is deemed as notice to all unions operating within its jurisdiction; therefore TAWUSA was effectively a party to the dispute.

The court reiterated the definition of the term "lock-out" as defined in section 213 of the LRA. ${ }^{49}$ It noted that the purpose of a lock-out in terms of section 213 is to compel employees whose trade union is party to certain negotiations to accede to an employer's demand. ${ }^{50}$ Accordingly, the court held that, as a matter of logic, there must be a dispute between an employer and employees or their trade union before a lock-out is implemented. ${ }^{51}$ Therefore, "any exclusion of employees from an employer's workplace that is not preceded by a demand in respect of a disputed matter of mutual interest does not qualify as a lockout in terms of section 213 of the LRA". ${ }^{52}$

Was there, in the present matter, a demand made by Putco to TAWUSA or its members? It should be noted that in oral argument it was contended on Putco's behalf that the lock-out notice given to TAWUSA constituted a demand. The court rejected this argument and held that the lock-out notice could not constitute a demand. This was so because a lock-out notice cannot constitute both a notice and a demand at the same time. The court explained as follows:

A lock-out notice cannot constitute both a notice and a demand at the same time. The LRA clearly distinguishes between a notice and a demand and does not use the two interchangeably. The purpose of a lock-out notice is to inform

Putco 3 para 1.

Putco 3 para 31.

Putco 3 para 32.

Putco 3 para 32.

Putco 3 para 32. 
a union and its members of an impending lock-out. In other words, recourse to a lawful lock-out must already be available. An employer is not entitled to resort to a lock-out if it has not yet made a demand to those employees who are to be excluded from the employer's workplaces. ${ }^{53}$

Furthermore, the court held that since TAWUSA was not a member of the Bargaining Council, no demand had been made to TAWUSA nor had it been in a position to accede to the demands Putco had made to the trade unions (SATAWU and TOWU) that were present at the Bargaining Council. ${ }^{54}$ In the light of the above findings, the court ultimately held that the purported lockout of TAWUSA's members did not comply with the definition of a lock-out as defined in section 213 of the LRA. ${ }^{55}$

Apart from non-compliance with the definition of a lock-out, the court also held that the purported lock-out did not comply with the provisions of section 64 of the LRA. The court held that the referral process (for conciliation) mandated by the LRA had not taken place. It reasoned that even though conciliation had taken place at the Bargaining Council and had been unsuccessful, this process had not involved TAWUSA because it had not been a party to the Bargaining Council. ${ }^{56}$ The appeal was upheld and the order of the court a quo set aside.

\subsection{Evaluation}

From the above, it is evident that both the Labour Court in Putco 1 and the Constitutional Court in Putco 3 ruled in favour of the trade union TAWUSA, whilst the Labour Appeal Court in Putco2 ruled in favour of the employer Putco.

Regarding Putco 1, the first thing that is apparent is the manner in which the court framed the issue to be determined by it, namely:

Crisply put, the question is whether an employer faced with a strike called by one or two unions can lawfully lockout all its employees inclusive of those not on strike, having not been called to strike by the union they belong to. ${ }^{57}$

By framing the issue in this manner, the court was basically asking whether the LRA allows secondary lock-outs. The LRA does not allow secondary lock-outs. ${ }^{58}$ Du Toit et a ${ }^{59}$ explain as follows:

\footnotetext{
$53 \quad$ Putco 3 para 36.

$54 \quad$ Putco 3 para 39.

55 Putco 3 para 40.

$56 \quad$ Putco 3 para 47.

$57 \quad$ Putco 1 para 8.

$58 \quad$ Du Toit et al Labour Relations Act 200-201; Van Niekerk and Smit Law@Work 439.

59 Du Toit et al Labour Relations Act 200-201. Also see Van Niekerk and Smit Law@Work 439,where they quote Du Toit et al with approval.
} 


\begin{abstract}
A lock-out [as defined in section 213 of the LRA] means 'the exclusion of employees by an employer for the purpose of compelling the employees to accept a demand...'. The use of the definite article 'the' for employees indicates, quite unequivocally, that it is the excluded (that is the locked out) employees whose compliance is sought. This would seem to rule out any possibility of a secondary lock-out which, by definition, is an exclusion to compel employees other than the locked out employees (that is the primary employees) to comply with demands.
\end{abstract}

This has serious implications for an employer faced with a strike by only part of its workforce. Under the previous Act the employer could have effected a complete discontinuance of operations (thus avoiding its obligation to pay those employees who continued to tender their services) by resorting to a lock-out of the entire workforce. The lock-out of the non-striking employees is effectively a secondary lock-out, which for the reasons we have shown, appears no longer contemplated by the definition. (Emphasis added; references omitted.)

It is submitted that in the light of the facts of the Putco matter, the manner in which the issue to be determined was framed by the court in Putco 3 was more appropriate:

The central question in this case is whether the Labour Relations Act (LRA) permits an employer to exclude from its workplaces, by way of a purported lock-out, members of a trade union that were not a party to a bargaining council where a dispute arose and was subsequently referred for conciliation. ${ }^{60}$

Be that as it may, the court in Putco 1 was indeed correct in focusing on section 213 (which defines the term lock-out) and section 64 (which lays down the procedural requirements for protected lock-outs) of the LRA. The LRA protects the right of every employee to strike and all employers' recourse to lock-out. ${ }^{61}$ However, strikes and lock-outs "are not absolute and must be exercised within the legal framework before such industrial actions are protected by law". ${ }^{62}$ This is provided for by the LRA. ${ }^{63}$ In terms of the LRA, a protected lock-out is one which complies with the provisions of chapter four of the LRA. ${ }^{64}$

In Putco 1, as was also the case in Putco 2 and 3, the court correctly held that a lock-out as defined by the LRA must be accompanied by a demand. ${ }^{65}$ The definition of the term lock-out in the LRA makes it abundantly clear that

$60 \quad$ Putco 3 para 1.

61 In terms of $s$ 64(1) of the LRA, which in part provides that "[e]very employee has the right to strike and every employer has recourse to lock-out..." S 64 should be read with s 65 , which deals with limitations on the right to strike and recourse to lock-out.

62 Samuel 2013 J Contemp Man 245.

63 Section 64 of the LRA read with ss 65 and 67 thereof.

64 Section 67 of the LRA.

$65 \quad$ Putco 1 para 12; Putco 2 para 41; Putco 3 para 32. 
the purpose of a lock-out is to compel employees or their trade unions to accede to an employer's demand. ${ }^{66} \mathrm{~A}$ demand must encompass more than simply requiring employees to perform their obligations in terms of their contracts of employment. ${ }^{67} \mathrm{~A}$ lock-out must always be accompanied by an express demand: for a demand to exist the locked out employees must be informed of the actions expected of them for the lock-out to be lifted. ${ }^{68}$ The Constitutional Court in Putco 3 affirmed that "the LRA requires an employer to make a perspicuous demand to employees before resorting to locking them out".69

In Putco 1 the court noted that it was loath to entertain a debate regarding whether or not the lock-out in question was a defensive or offensive one. However, as is shown below, the question of whether or not a lock-out is defensive or offensive is a key consideration in determining whether an employer may use replacement labour during a strike by its employees.

\section{The Sun International case}

\subsection{The facts}

The trade union SACCAWU (South African Commercial, Catering and Allied Workers' Union) embarked on a protected strike of limited duration and issued a notice in terms of section 64 of the LRA on 21 September 2015. The notice informed Sun International (the employer) that the strike would start on 25 September 2015. The dispute involved demands for wage increases, minimum working hours and a housing subsidy.

On 22 September 2015, three days before the strike was set to commence, the employer issued a notice, the heading of which read as follows: "Notification of the commencement of a lockout in terms of section 64(1)(c) read with section 76(1)(b) Labour Relations Act, 66 of 1995, as amended (the LRA)". The lock-out was set to commence on 25 September 2015.

Feeling aggrieved by the said notice, SACCAWU approached the Labour Court on an urgent basis where it sought a declaratory and interdictory order in the following terms:

Declaring that the Respondent's unlimited duration lock-out is not meant to counteract the effect of the strike action by the Applicant's members and is,

66 Grogan Collective Labour Law 312; Todd Collective Bargaining Law 71; Du Toit et al Labour Relations Act 200-201; Van Niekerk and Smit Law@Work 439; Putco 3 para 32; Technikon SA para 15.

67 Van Niekerk and Smit Law@Work 439; Du Toit et al Labour Relations Act 201.

68 Grogan Collective Labour Law 310.

$69 \quad$ Putco 3 para 35. 
therefore, not in response thereto as envisaged by the latter part of the

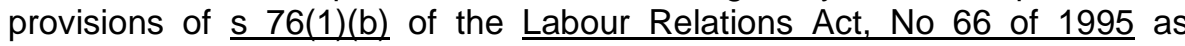
amended; and

Interdicting and Restraining the Respondent forthwith from taking into its employment any person for the purpose of performing the work of any employee who is locked out by virtue of a lock-out issued by the Respondent on 22 September $2015 .^{70}$

\subsection{The judgment}

The court identified the issue to be determined as whether in terms of section 76(1)(b) of the LRA an employer may continue to use replacement labour after a strike has ended. ${ }^{71}$ For convenience, it should be noted that section 76 of the LRA is titled "Replacement labour" and provides that:

(1) An employer may not take into employment any person-

(a) to continue or maintain production during a protected strike if the whole or a part of the employer's service has been designated a maintenance service; or

(b) for the purpose of performing the work of any employee who is locked out, unless the lock-out is in response to a strike.

(2) For the purpose of this section, 'take into employment' includes engaging the services of a temporary employment service or an independent contractor.

Although the trade union conceded that the lock-out in question was protected, it argued that an employer's right to use replacement labour must be in response to a strike and that once a strike has ended, section 76(1)(b) of the LRA no longer applies. On the other hand, the employer argued that, taking into account the interpretation clause contained in the LRA, it is entitled to use replacement labour in a context in which the employer reacts to a strike by means of a protected lock-out, even after the end of such strike. It would be anomalous, so the argument went, that an employer is entitled to meet a union's attack by way of a counter-attack (in the form of a lock-out), but with its right to an effective counter-attack being limited by a factor of the attacker's choice - the duration of the hostilities.

The employer relied on an earlier judgment of the Labour Court in Ntimane $\checkmark$ Agrinet $^{72}$ where the court had held that the right to employ replacement labour accrues at the stage when a defensive lock-out is implemented and endures until the lock-out ceases. ${ }^{73}$ Put differently, the court in Ntimane held

Sun International case para 1.

Sun International case para 5.

Ntimane v Agrinet 199920 ILJ 809 (LC) (hereafter Ntimane).

See Ntimane. 
that if an employer implements a defensive lock-out (a lock-out in response to a strike) it does not lose the right to employ replacement labour should its employees decide to terminate their strike. For its part, SACCAWU relied on yet another earlier judgment of the Labour Court in National Union of Technikon Employees $v$ Technikon, ${ }^{74}$ where the court had stated (obiter) that "if the strike ends so must the employment of replacement labour". ${ }^{75}$

In the light of the above conflicting judgments, the court had to decide whether or not to follow Ntimane. For the reasons outlined below and discussed in more detail later, the court decided not to follow Ntimane. The court considered the meaning of the words "in response to a strike" in section 76(1)(b) of the LRA. Relying on a number of authorities including the Certification Judgment ${ }^{76}$ and the International Labour Organisation's (the ILO) Committee of Experts, ${ }^{77}$ the court held that the statutory right of an employer to use replacement labour is restricted to the period during which a protected strike continues and not after it has ended. ${ }^{78}$

\subsection{Evaluation}

In order to understand why section 76 of the LRA is drafted in the way it is, it is perhaps helpful to start by providing some historical context. ${ }^{79}$

The early 1990s were marked by major political and legal changes in South Africa. For example, President De Klerk announced the unbanning of several organisations including the African National Congress (ANC), the release of political prisoners (including Nelson Mandela) and the repeal of apartheid legislation. ${ }^{80}$ The negotiations between the government and the ANC which began in 1991 eventually led to an agreement on an interim constitution $^{81}$ and culminated in the April 1994 elections. ${ }^{82}$ Given the prominent role played by trade unions in bringing down apartheid, much

\footnotetext{
$74 \quad$ National Union of Technikon Employees v Technikon 200021 ILJ 1645 (LC).

$75 \quad$ National Union of Technikon Employees $v$ Technikon 200021 ILJ 1645 (LC) para 9.

76 Certification case, where the Constitutional Court rejected the proposition that the right of employers to lock out is the necessary equivalent of the right of workers to strike.

77 Which stated - with reference to the ILO's Right to Organise and Collective Bargaining Convention (No 98 of 1949) - that workers who participate in a lawful strike should be able to work once the strike has ended.

78 Sun International case paras 13-19.

79 An in-depth discussion of the history and development of the LRA is beyond the scope of this article. Therefore, only the development of the LRA in relation to replacement labour is considered.

80 Du Toit et al Labour Relations Act 17.

81 Constitution of the Republic of South Africa (Interim), 1993 - hereafter the Interim Constitution.

82 Du Toit et al Labour Relations Act 17.
} 
emphasis was placed on labour rights in the new dispensation. ${ }^{83}$ The following labour rights were entrenched in the Interim Constitution: the right to fair labour practices; the right to form and join trade unions; the right to organise and bargain collectively; and the right to strike. ${ }^{84}$ Significantly, an employer's recourse to lock-out for the purpose of collective bargaining was also protected in the Interim Constitution. ${ }^{85}$

Within a short time of assuming power, the new, democratically elected ANC-led government announced its intention to introduce a new labour relations statute. ${ }^{86}$ There was a need to bring the Labour Relations Act into line with the Interim Constitution. ${ }^{87}$ The Interim Constitution was therefore one of the main incentives for reforming the Labour Relations Act. ${ }^{88} \mathrm{~A}$ commission was appointed to produce a draft Labour Relations Bill. The draft produced by the commission formed the basis of the current LRA. ${ }^{89}$

One of the major defects of the 1956 LRA was its failure to provide striking employees with any protection against dismissal. ${ }^{90}$ The other defects of the 1956 LRA with respect to strike law included complicated and technical prestrike procedures, onerous ballot provisions, the criminalisation of strikes and lock-outs, the prohibition of socio-economic strikes and the ready availability of interdicts and damages claims. ${ }^{91}$ It is important to note that the 1956 LRA was silent on the issue of replacement labour. ${ }^{92}$ However, it seems that what the law did not prohibit the law allowed.

In February 1995 a new body called the National Economic Development and Labour Council (NEDLAC) was launched. It is a body consisting of representatives of organised labour, employers and government. ${ }^{93}$ All legislation relating to labour has to serve before NEDLAC, where the parties seek to reach consensus before it is sent to Parliament. ${ }^{94}$

By the time negotiations commenced on the Draft Labour Relations Bill of 1995, business and labour had adopted very different positions on a number

83 Grogan Collective Labour Law 6.

$84 \quad$ Section 27 of the Interim Constitution.

85 Section 27(5) of the Interim Constitution.

86 Du Toit et al Labour Relations Act 17.

87 Explanatory Memorandum to the Labour Relations Bill (1995 16 ILJ 278) 281.

88 Du Toit et al Labour Relations Act 17.

89 Grogan Collective Labour Law 6.

90 Explanatory Memorandum to the Labour Relations Bill (1995 16 ILJ 278) 299; Du Toit et al Labour Relations Act 26.

91 Explanatory Memorandum to the Labour Relations Bill (1995 16 ILJ 278) 300.

$92 \quad$ Satgar 1998 LDD 49 note 8.

93 Grogan Collective Labour Law 6-7; Du Toit et al Labour Relations Act 18-19. Also see the National Economic Development and Labour Council Act 35 of 1994.

94 Du Toit et al Labour Relations Act 18-19. Also see the National Economic Development and Labour Council Act 35 of 1994. 
of key points. ${ }^{95}$ The use of replacement labour during protected strike action was one of the "key points of contention" during consultation on the proposed Draft Bill. ${ }^{96}$ Business South Africa wanted strikes and lock-outs to be allowed once the correct procedure (including a strike ballot) had been followed. It also submitted that employers should retain their right to replace striking workers. ${ }^{97}$ On the other hand, trade unions were adamant that replacement labour or scab labour should not be allowed during a procedural strike. ${ }^{98}$ One of the issues which the drafters of the Draft Bill considered was the effect of a protected strike on an employer. Keeping in mind the extensive protection afforded to employees who participate in protected strike action by the Draft Bill, they reasoned that "it is through the resolution of the dispute or continued production, with the use of an alternative workforce, that the company's viability can best be maintained". 99 Therefore, the Draft Bill offered an employer facing bankruptcy three options: resolve the dispute, employ temporary replacement labour or dismiss the striking workers on grounds of operational requirements. ${ }^{100}$

Negotiations on the Draft Bill were concluded on 21 July 1995. Although business and labour had reached consensus on a number of key points of contention, they had failed to reach consensus on the use of replacement labour. ${ }^{101}$ NEDLAC referred the Draft Bill to the Cabinet. Cabinet ratified the Bill and on 13 September 1995 the LRA was passed by Parliament. ${ }^{102}$

Although trade unions have argued for a total ban on replacement labour in South Africa ${ }^{103}$ they have clearly not yet achieved this goal since, as was noted earlier, section 76 of the LRA allows the use of replacement labour during strikes. For example, employers are allowed to employ replacement labour during a defensive lock-out - a lock-out "in response to a strike". ${ }^{104}$ By contrast, if an employer initiates industrial action by implementing a lock-

95 The position of Business South Africa on the Draft Labour Relations Bill of 1995 was set out in a document titled "A Framework for Redrafting the Labour Relations Act (1995)". On the other hand, the position of organised labour was set out in a document (unpublished) titled "Proposals on the Draft Labour Relations Bill: Summary of COSATU, NACTU and FEDSAL Proposals (1 May 1995)". See Du Toit et al Labour Relations Act 28 note 134.

96 Du Toit et al Labour Relations Act 29.

97 Du Toit et al Labour Relations Act 29-30.

98 Du Toit et al Labour Relations Act 29-30.

$99 \quad$ Explanatory Memorandum to the Labour Relations Bill (1995 16 ILJ 278) 305.

100 Explanatory Memorandum to the Labour Relations Bill (1995 16 ILJ 278) 305.

101 Du Toit et al Labour Relations Act 32.

102 Du Toit et al Labour Relations Act 32.

103 See Hepple and Leroux Laws Against Strikes 34; Todd Collective Bargaining Law 76; Bendix Industrial Relations 613.

104 Section 76(1)(b) of the LRA. 
out in the absence of a strike (an offensive lock-out), it may not employ replacement labour. ${ }^{105}$ According to Grogan, this prohibition is aimed at balancing the scales when employers resort to lock-outs. He submits that without it there would be no inducement for employers to lift lock-outs, which could endure indefinitely if the employer manages to keep its business running. ${ }^{106}$ In Technikon SA v National Union of Technikon Employees, ${ }^{107}$ the Labour Appeal Court explained the rationale behind section 76(b) of the LRA as follows:

The rationale behind $s 76(1)(b)$ is that if an employer decides to institute a lock-out as the aggressor in the fight between itself and employees or a union, it may not employ temporary replacement labour. That is to discourage the resort by employers to lock-outs. The rationale is to try and let employers resort to lock-outs only in those circumstances where they will be prepared to do without replacement labour (i.e. when they are the aggressors) or where they are forced to in self-defence in the sense that the lock-out is 'in response to' a strike by the union and the employees - in other words, where the union and the employees are the aggressors. ${ }^{108}$

Returning to the Sun International matter, it is obvious that this case turned on the interpretation of the words "in response to a strike" as used in section 76(1)(b) of the LRA. Do these words mean that the right to employ replacement labour accrues at the stage when a defensive lock-out is implemented and endures until the lock-out ceases, as was held in Ntimane? Or do they mean that the statutory right of an employer to use replacement labour is restricted to the period during which a protected strike continues and not after it has ceased, as was held in Sun International?

The facts of both cases are strikingly similar. In Ntimane there was a dispute between the trade union SACCAWU and the employer regarding wage negotiations. The employees engaged in a protected strike and the employer responded by instituting a lock-out. The lock-out was in response to the strike. The trade union informed the employer that it did not accept the employer's demands but was calling off the strike. In turn, the employer informed the trade union that the lock-out would continue until such time as its offer had been accepted by the union's members.

The starting point in determining the true meaning of the words "in response to a strike" as used in section 76(1)(b) of the LRA is the LRA itself. As Grogan points out, the unusual aspect of the LRA is that it contains a

105 Section 76(1)(b) of the LRA.

106 Grogan Collective Labour Law 315.

107 Technikon SA v National Union of Technikon Employees of SA 200122 ILJ 427 (LAC).

108 Technikon SA para 40. 
specific interpretation clause. ${ }^{109}$ Section 3 of the Act compels any person applying the Act to interpret its provisions (a) to give effect to its primary objects; (b) in compliance the Constitution; and (c) in compliance with the public international law obligations of South Africa. ${ }^{110}$

Section 3 sanctions a purposive model of statutory interpretation as opposed to a literal approach. ${ }^{111}$ The objects of the Act are not simply textual aids. They "must inform the interpretative process from its inception". ${ }^{112}$ In other words, the Act must be read in the light of its objects. ${ }^{113}$ As was noted earlier, section 23 of the Constitution specifically deals with labour relations. Therefore, the LRA must be interpreted in the light of the Constitution, especially section 23 thereof. Put differently, the interpretation clause of the LRA emphasises that the Act must be interpreted to give effect to the constitutional rights. ${ }^{114}$

In Sun International, the court emphasised the interpretation clause and the fact that "the constitutionally protected right to strike is not equivalent to the statutory right to lock-out as provided by the LRA". ${ }^{115}$ Indeed, it is correct that South African law does not treat strikes and lock-outs as equal "weapons". ${ }^{116}$ Unlike the Interim Constitution, ${ }^{117}$ the (final) Constitution of South Africa protects the right to strike but excludes the right to lock-out. In addressing this issue directly, the Constitutional Court in the Certification case rejected the argument that "it is necessary in order to maintain equality to entrench the right to lock out once the right to strike has been included". ${ }^{118}$

According to Creamer, this approach - the Constitution's protection of the right to strike and its silence on the lock-out - heralds a new approach to the regulation of industrial action in South Africa, based on the "'asymmetrical parity' conception". ${ }^{119}$ Keeping in mind this asymmetrical parity conception, the court in Sun International held that the statutory right of an employer to use replacement labour is restricted to the period during which a protected strike continues and not after it has ended. ${ }^{120}$ Moreover,

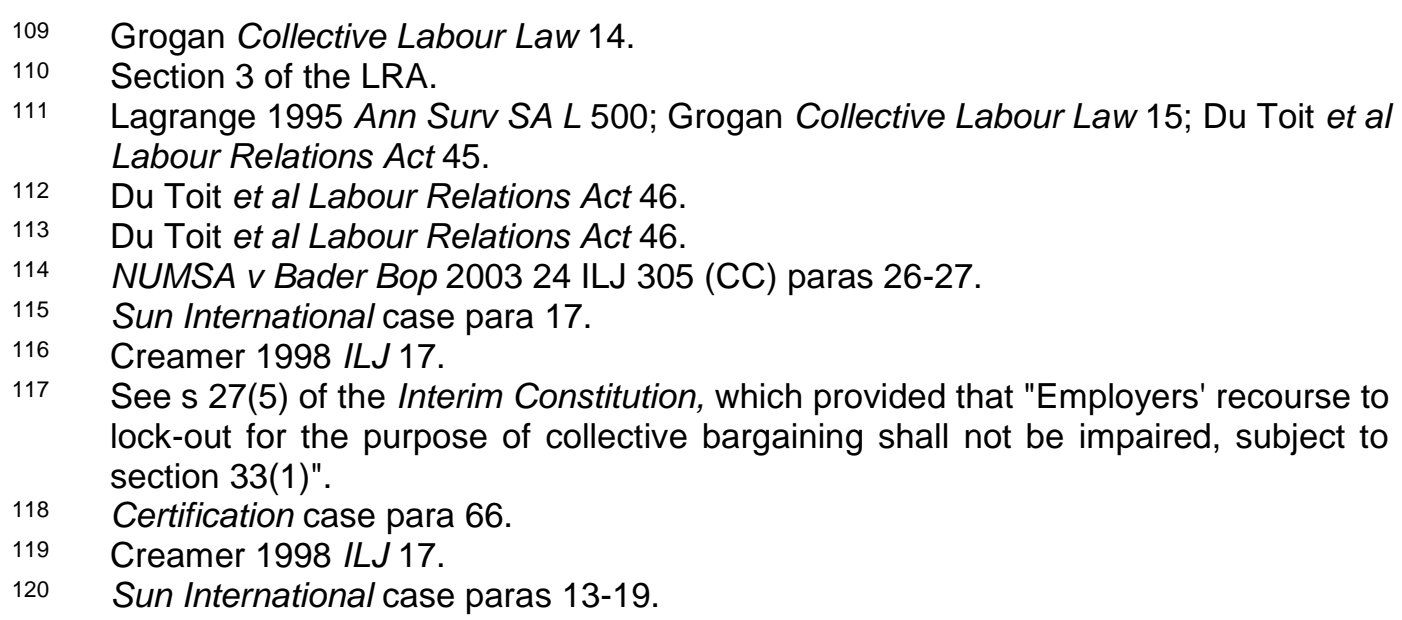


the court cited the ILO's Committee of Experts ${ }^{121}$ where the latter had stated that workers who participate in a lawful strike should be able to return to work once the strike has ended. ${ }^{122}$

It seems to be common cause that the lock-out in Sun International, which was implemented by the employer on 25 September 2015, was in response to a strike by its employees, which commenced on the same day. ${ }^{123}$ Also, it seems that it was common cause that the termination of the said strike did not affect the legality of the lock-out: it remained a protected lock-out and the employer was not required to comply anew with the procedural requirements set out in section 64 of the LRA. ${ }^{124}$ Put differently, the lock-out (even after the strike had been terminated) was the unbroken continuation of the action which the employer had embarked upon on 25 September 2015. ${ }^{125}$ As the court put it in Ntimane, "a chameleon remains a chameleon even after it has changed its hue". ${ }^{126}$

It is important to emphasise that in Sun International the workers called off their strike without accepting the employer's final offer - there was an ongoing dispute and the employer was therefore entitled to continue with the lock-out. ${ }^{127}$ Under these circumstances, given the court's reliance on the ILO's Committee of Experts, where the latter had stated that workers who participate in a lawful strike should be able to return to work once the strike has ended, were the employees in Sun International able to return to work once they had terminated their strike? It is submitted that they were not entitled to do so whilst the lock-out was in place.

If one were to follow the reasoning of the court in Sun International it would mean that the employer's lock-out remained the same protected lock-out for the purposes of section 64 of the LRA but at the same time changed (when the employees terminated their strike) into an offensive lock-out for the purposes of section 76(1)(b) of the LRA - which meant that the employer was no longer allowed to employ replacement labour. This cannot be correct

121 Which stated - with reference to the ILO's Right to Organise and Collective Bargaining Convention (No 98 of 1949) - that workers who participate in a lawful strike should be able to work once the strike has ended.

122 Sun International case para 17.

123 In part, the lock-out notice provided that "the lockout will commence after members of SACCAWU have embarked on their strike".

124 Sun International case para 5.

125 In part, the lock-out notice provided that "the lockout will continue until such time as Sun International's aforesaid offer has been accepted..."

$126 \quad$ Nimane para 10.

127 SACCAWU conceded that the lock-out was protected. See Sun International case para 5. 
since the employer instituted only one lock-out, in response to the strike by its employees.

Moreover, section 76(1)(b) of the LRA does not provide that the exception therein is rendered inapplicable when the strike in response to which the lock-out was initiated terminates. ${ }^{128}$ In Sun International the court applied purposive interpretation to reach the conclusion that the statutory right of an employer to use replacement labour is restricted to the period during which a protected strike continues and falls away after it has ceased. Although the LRA endorses purposive statutory interpretation, purposive interpretation is no license to ignore the clear language used in the Act. In Technikon SA v National Union of Technikon Employees of SA, ${ }^{129}$ Zondo JP (as he then was) stated the following about purposive interpretation:

\begin{abstract}
It seems warranted that I should repeat what I said two years ago in the Labour Court about purposive interpretation. In Transportation Motor Spares $v$ National Union of Metalworkers of SA \& others (1999)20 ILJ 690 (LC) at 699B I said: 'While purposive interpretation has much to its credit, nevertheless, it must be adopted in appropriate cases. Purposive interpretation is no licence to ignore the language used in the statute which is the subject of interpretation.' There is, accordingly, no justification for reading into s 76(1)(b) a word which is not there. ${ }^{130}$
\end{abstract}

The above case is a good example of an instance where a trade union, relying on purposive interpretation, sought to convince the court to interpret narrowly an employer's right to employ temporary replacement labour in terms of section 76(1)(b) of the LRA. In this case, the trade union argued that the phrase "in response to a strike" in section 76(1)(b) of the LRA should be interpreted as referring to unprotected strikes only. The Labour Appeal Court, correctly it is submitted, rejected this argument. ${ }^{131}$ In SACTWU $v$ Coats $^{132}$ the court said the following about purposive interpretation:

The purposive approach is applied in order to give effect to the purpose or ratio of a statute. If the purpose of the statute is evident from the language used, the words used must be given their ordinary meaning. The purposive approach is not a licence to ignore the plain meaning of the language. Technikon SA v National Union of Technikon Employees of SA (2001) 22 ILJ 427 (LAC); [2001] 1 BLLR 58(LAC).

There is no ambiguity about the words 'take into employment'. They were deliberately used to exclude those who are not already in employment. If the legislature had intended the section to have the meaning that Mr Pillemer

\footnotetext{
$128 \quad$ Ntimane para 16.

129 Technikon SA v National Union of Technikon Employees of SA 200122 ILJ 427 (LAC).

130 Technikon SA para 41.

131 Technikon SA paras 34-39.

132 SACTWU $v$ Coats 200122 ILJ 1413 (LC).
} 
seeks to attach to the words 'take into employment' then it could simply have used the word 'employ' instead of 'take into employment'. 133

In the light of the above, it is submitted that the court in Ntimane was correct in its interpretation of section 76(1)(b) of the LRA. Grogan states that "if a lock-out commences as a 'defensive' lock-out (i.e. in response to a strike) and the workers subsequently abandon their strike, the right to employ replacement labour continues". ${ }^{134}$ Furthermore, we also agree with the court in Ntimane that the employer's right to continue using replacement labour is counterbalanced by the right to picket. ${ }^{135}$ Section 69 of the LRA affords members of a trade union the right to picket in support of a protected strike or in opposition to any lock-out. The right to picket is reinforced by the fundamental rights to freedom of expression ${ }^{136}$ and freedom of assembly ${ }^{137}$ as guaranteed by the Constitution. ${ }^{138}$ The position of the LRA is in line with that of the ILO. According to the ILO, taking part in picketing and firmly but peacefully inciting other workers to keep away from their workplace cannot be considered unlawful. ${ }^{139}$ It is submitted that the "other workers" referred to by the ILO include replacement workers. Importantly, in the South African context, there is a Code of Good Practice on Picketing. ${ }^{140}$ Item 3 thereof provides that:

The purpose of the picket is to peacefully encourage non-striking employees and members of the public to oppose a lock-out or to support strikers involved in a protected strike. The nature of this support can vary. It may be to encourage employees not to work during the strike or lock-out. It may be to dissuade replacement labour from working. It may also be to persuade members of the public or other employers and their employees not do business with the employer. (Own emphasis.)

There was therefore nothing in the Sun International matter which would have prevented the employees from firmly but peacefully picketing to dissuade replacement labour from working.

133 SACTWU v Coats 200122 ILJ 1413 (LC) paras 6-7.

134 Grogan Workplace Law 488. Also see Todd Collective Bargaining Law 77, who states that "[i]f a lock-out is implemented in response to a strike, then replacement labour is permitted. This remains so even if the strike (in response to which the lockout was implemented) has come to an end". $v$ Technikon2000 21 ILJ 1645 (LC) para 12 (it should be noted that this judgment was overturned by the Labour Appeal Court on appeal). 


\section{Concluding remarks}

South African labour legislation is based on a rigid adversarial system. ${ }^{141}$ Currently, as Levy has pointed out, one of the complicating features of collective bargaining in South Africa is the extent and nature of what can only be described as "bad faith bargaining". ${ }^{142}$ Negotiations are characterised by unions tabling extreme demands and then showing an unwillingness to move. ${ }^{143}$ Consequently, this sort of (bad faith) bargaining may increase both the probability and the length of a strike. ${ }^{144}$

It is important for trade unions to properly understand the implications of their actions before acting on behalf of their members. They need to be aware of the fact that when they initiate industrial action in the form of a strike there are certain legal consequences which are favourable and not so favourable to their members. On the favourable side, for example, is the protection against dismissal. It has been described as "the most meaningful protection for strikes that comply with the Act"145 and "the most valuable protection offered to employees". ${ }^{146}$ On the not so favourable side, for example, is the risk of being dismissed for operational requirements. Also, and more relevant, is the fact that employers have the right to replace striking workers - with or without a lock-out. The comments made by the Labour Appeal Court in Technikon SA v National Union of Technikon Employees of $S A$ are apposite, where it said:

The policy [rationale behind section $76(1)(b)$ of the LRA] is one that also says to unions and employees: Do not lightly resort to a strike when a dispute has arisen because, in the absence of a strike, the employer may not employ replacement labour even if it institutes a lock-out but, if you strike, the employer will be able to employ replacement labour - with or without a lockout. The sum total of all this is that the policy is to encourage parties to disputes to try to reach agreement on their disputes and a strike or lock-out should be the last resort when all reasonable attempts to reach agreement have failed. ${ }^{147}$

On a broader note, the Sun International matter exposes some of the controversial aspects of replacement labour. It has been argued that allowing the use of replacement labour is one of the factors that have tilted the balance of power in favour of employers in relation to collective bargaining, and that the use of replacement labour during strikes may affect

\footnotetext{
141 See Davis and Le Roux 2012 Acta Juridica 315.

142 Levy "An examination of industrial action: 2013" 20.

143 Levy "An examination of industrial action: 2013" 20.

144 Levy "An examination of industrial action: 2013" 20.

145 Du Toit et al Labour Relations Act 215.

146 Van Niekerk and Smit Law@Work 434.

147 Technikon SA para 43.
} 
the effectiveness of a strike and thus prolong it. ${ }^{148}$ The Department of Labour has identified the use of replacement labour as one of the key reasons behind the increasing length of strikes in South Africa. ${ }^{149}$

The persuasive force of a strike largely depends upon the extent to which striking workers are able to interrupt the employer's business or production by withdrawing their labour. ${ }^{150}$ The ILO regards the right to strike as constituting a fundamental right of workers and as an essential aspect of trade union rights, ${ }^{151}$ and the Committee on Freedom of Association has always recognised the right to strike by workers and their organisations "as a legitimate means of defending their economic and social interests". ${ }^{152}$ Employers want to be able to employ persons to maintain production during a strike or lock-out. However, from the employees' point of view the use of replacement labour deprives them of the only "weapon" that they have, namely, the ability to withhold their labour and thereby place economic pressure on the employer. ${ }^{153}$ It therefore prima facie seems odd to entrench the right of workers to strike whilst at the same time allowing the employer to simply replace them when they exercise that right.

Violence during strikes has become a serious concern in South Africa. ${ }^{154}$ Instead of being characterised by orderly picket lines, South Africa has "one of the highest rates of industrial action, with its strikes amongst the most violent in the world". ${ }^{155}$ It has been said that the use of replacement labour increases the potential for conflict and violence. ${ }^{156}$ According to Tenza, ${ }^{157}$ it "has turned out to be the root cause of violent strikes". Strike violence usually breaks out when the employer attempts to continue operating during the strike. ${ }^{158}$ Workers who assist the employer to maintain production during a strike and so undermine the effect of the strike are also colloquially referred to as "scabs". ${ }^{159}$ There have been numerous instances where people who were scabs or were considered to be scabs were either

\footnotetext{
$148 \quad$ Ndungu 2009 Int'l J Labour Res 91.

149 Department of Labour Annual Industrial Action Report 201033.

150 Todd Collective Bargaining Law 76.

151 ILO Freedom of Association paras 131, 520.

152 ILO Freedom of Association para 521.

153 Du Toit et al Labour Relations Act 241.

154 Manamela and Budeli 2013 CILSA 322. Also see Rycroft 2015 ILJ 2; Benjamin 2014 ILJ 10; Von Holdt 2010 Transformation 127; Masiloane 2010 Acta Criminologica 31; Botha 2015 De Jure 344.

Odendaal 2014 http://www.miningweekly.com/article/sa-one-of-the-worlds-mostviolent-strike-prone-countries-2014-08-06.

156 McQuarrie Industrial Relations in Canada 257; Todd Collective Bargaining Law 76.

157 Tenza 2015 LDD 219-222.

158 Stewart and Townsend $1966 \cup$ Pa L Rev 460.

159 Todd Collective Bargaining Law 76.
} 
assaulted or killed. This is not a new phenomenon. Five scabs were killed during the 1987 strike by railway workers. ${ }^{160}$

Although trade unions have argued for a total ban on replacement labour in South Africa, ${ }^{161}$ they have not been successful thus far. The drafters of the LRA viewed the use of replacement labour from the perspective of both employees and employer. Jordaan ${ }^{162}$ argues that a total ban on replacement labour would mean that the employer was denied the right to do business. He submits that a substantial case based on public policy would have to be made out why this should be the case. For him, the mere fact that replacement labour may reduce the effectiveness of a strike is simply insufficient. ${ }^{163}$

The Putco and Sun International cases highlight some of the defensive industrial weapons that are available to an employer when faced with a strike. In the Putco matter the Constitutional Court as the highest court in the country spoke in a unanimous judgment. This case will now serve as a clear reminder to all employers that a lock-out must be preceded by a demand to the employees who are to be excluded from the workplace. As was noted earlier, it is important to emphasise that in Sun International the workers called off their strike without accepting the employer's final offer there was an ongoing dispute and the employer was therefore entitled to continue with the lock-out. ${ }^{164}$

Regarding the proper interpretation of section 76(1)(b) and the use of replacement labour, it is only the Constitutional Court that can provide a definitive interpretation of the phrase "in response to a strike". The conflicting judgments of the Labour Court in Ntimane and Sun International will most likely lead to a lot of unnecessary confusion. Therefore, it is important that this issue be settled sooner rather than later.

\footnotetext{
160 Anstey 2013 SAJLR 141. Also see NUMSA v GM Vincent 19914 SA 304 (SCA); S $\checkmark$ Matshili 19913 SA 264 (A); National Construction Building and Allied Workers Union v Betta 199920 ILJ 1617 (CCMA); FAWU v National Co-operative Dairies 198910 ILJ 490 (IC); FAWU v Premier Foods 201031 ILJ 1654 (LC). More recently, see Mahlangu v SA Transport \& Allied Workers Union 201435 ILJ 1193 (GSJ).

161 Hepple and Leroux Laws Against Strikes 34; Todd Collective Bargaining Law 76; Bendix Industrial Relations 613.

162 Jordaan 1997 LDD 4.

163 Jordaan 1997 LDD 4.

164 SACCAWU conceded that the lock-out was protected. See Sun International case para 5.
} 


\section{Bibliography}

\section{Literature}

Anstey 2013 SAJLR

Anstey M "Marikana - and the Push for a New South African Pact" 2013 SAJLR 133-145

\section{Bendix Industrial Relations}

Bendix S Industrial Relations in South Africa $5^{\text {th }}$ ed (Juta Cape Town 2010)

Benjamin 2014 ILJ

Benjamin P "Beyond Dispute Resolution: The Evolving Role of Commissioner for Conciliation and Arbitration" 2014 ILJ 1-29

Botha 2015 De Jure

Botha MM "Responsible Unionism during Collective Bargaining and Industrial Action: Are we there yet?" 2015 De Jure 328-350

Botha 2015 Obiter

Botha MM "What Constitutes a Matter of Mutual Interest in Relation to a Strike? A Tale of Two Recent Cases" 2015 Obiter 194-209

Creamer 1998 ILJ

Creamer $\mathrm{K}$ "The Meaning and Implications of the Inclusion in the Constitution of a Right to Strike and the Exclusion of a Lock-out Right: Towards Asymmetrical Parity in the Regulation of Industrial Action" 1998 ILJ 1-23

Davies and Freedland Khan Freud's Labour and the Law

Davies P and Freedland M (eds) Khan Freud's Labour and the Law $3^{\text {rd }}$ ed (Stevens London 1983)

Davis and Le Roux 2012 Acta Juridica

Davis D and Le Roux M "Changing the Role of Corporation: A Journey Away from Adversarialism" 2012 Acta Juridica 306-325

Department of Labour Annual Industrial Action Report 2006

Department of Labour Annual Industrial Action Report 2006 (Government Printers Pretoria 2006)

Department of Labour Annual Industrial Action Report 2010

Department of Labour Annual Industrial Action Report 2010 (Government Printers Pretoria 2010) 
Department of Labour Annual Industrial Action Report 2014

Department of Labour Annual Industrial Action Report 2014 (Government Printers Pretoria 2014)

Department of Labour Annual Industrial Action Report 2015

Department of Labour Annual Industrial Action Report 2015 (Government Printers Pretoria 2015)

Du Toit 2007 ILJ

Du Toit D "What is the Future of Collective Bargaining (and Labour Law) in South Africa?" 2007 ILJ 1405-1435

Du Toit et al Labour Relations Act

Du Toit D et al The Labour Relations Act of 1995 (Butterworths Durban 1998)

Grogan Collective Labour Law

Grogan J Collective Labour Law (Juta Cape Town 2010)

Grogan Workplace Law

Grogan J Workplace Law $11^{\text {th }}$ ed (Juta Cape Town 2014)

Godfrey et al Collective Bargaining

Godfrey et al Collective Bargaining in South Africa: Past, Present \& Future? (Juta Cape Town 2010)

Hepple and Leroux Laws against Strikes

Hepple B and Leroux S (eds) Laws against Strikes (FrancoAngeli Milan 2015)

Jordaan 1997 LDD

Jordaan B "Collective Bargaining under the New Labour Relations Act: The Resurrection of Freedom of Contract" 1997 LDD 1-9

ILO Freedom of Association

ILO Freedom of Association: Digest of Decisions and Principles of the Freedom of Association Committee of the Governing Body of the ILO $5^{\text {th }}$ ed (International Labour Office Geneva 2006)

Lagrange 1995 Ann Surv SA L

Lagrange R "Labour Law" 1995 Ann Surv SA L 498-580

Levy "Strike Action"

Levy A "Strike Action: Will Things Ever be the Same" in Levy A and Motshabi K (eds) The Dispute Resolution Digest 2013 (Juta Cape Town 2013) $5-20$ 
Levy "An examination of industrial action: 2013"

Levy A "An examination of industrial action: 2013" in Levy and Motshabi (eds) The Dispute Resolution Digest 2014 (Juta Cape Town 2014) 5-24

Manamela and Budeli 2013 CILSA

Manamela $E$ and Budeli M "Employee's Right to Strike and Violence in South Africa" 2013 CILSA 308-336

Masiloane 2010 Acta Criminologica

Masiloane D "Guaranteeing the Safety of Non-striking Employees during Strikes: The Fallacy of Policing" 2010 Acta Criminologica 31-41

McQuarrie Industrial Relations in Canada

McQuarrie F Industrial Relations in Canada $4^{\text {th }}$ ed (Wiley Toronto 2015)

Myburgh 2004 ILJ

Myburgh J "100 Years of Strike Law" 2004 ILJ 962-976

National Planning Commission 2012

National Planning Commission "National Development Plan 2030: Our Future - Make it Work" 2012

Ndungu 2009 Int'l J Labour Res

Ndungu S "Perspectives on Collective Bargaining in the Global South: The Case of South Africa" 2009 Int'l J Labour Res 81-98

Rycroft 2015 ILJ

Rycroft A "Strikes and Amendments to the LRA" 2015 ILJ 1-20

Samuel 2013 J Contemp Man

Samuel M "The Mineworkers' Unprocedural Strike: Setting the Path for Redefining Collective Bargaining Practice in South Africa" $2013 \mathrm{~J}$ Contemp Man 238-258

\section{Satgar $1998 \angle D D$}

Satgar V "The LRA and Work-place Forums: Legislative Provisions, Origins, and Transformative Possibilities" 1998 LDD 42-63

Stewart and Townsend $1966 \cup \mathrm{Pa} L \mathrm{ReV}$

Stewart $\mathrm{F}$ and Townsend $\mathrm{R}$ "Strike Violence and the Need for Federal Injunctions" 1966 U Pa L Rev 459-486

Tenza $2015 L D D$

Tenza M "An Investigation into the Causes of Violent Strikes in South Africa: Some Lessons from Foreign Law and Possible Solutions" 2015 LDD 211231 
Todd Collective Bargaining Law

Todd C Collective Bargaining Law (Siber Ink Cape Town 2004)

Van der Welden and Dribbusch Strikes Around the World

Van der Welden S and Dribbusch H (eds) Strikes Around the World 19652005: Case-Studies of 15 Countries (Ascant Amsterdam 2007)

Van Niekerk and Smit Law@Work

Van Niekerk A and Smit N (eds) Law@Work $3^{\text {rd }}$ ed (LexisNexis Durban 2015)

Von Holdt 2010 Transformation

Von Holdt K "Institutionalisation, Strike Violence and Local Moral Orders" 2010 Transformation 127-151

\section{Case law}

Betha v BTR Sarmcol (a Division of BTR Dunlop Ltd) 199819 ILJ 459 (SCA)

FAWU v National Co-operative Dairies 198910 ILJ 490 (IC)

FAWU v Premier Foods 201031 ILJ 1654 (LC)

In re Certification of the Constitution of the Republic of South Africa, 1996 19964 SA 744 (CC)

Mahlangu v SA Transport \& Allied Workers Union 201435 ILJ 1193 (GSJ)

National Construction Building and Allied Workers Union v Betta 199920 ILJ 1617 (CCMA)

National Union of Technikon Employees v Technikon 200021 ILJ 1645 (LC)

Ntimane v Agrinet 199920 ILJ 809 (LC)

NUMSA v Bader Bop 200324 ILJ 305 (CC)

NUMSA v GM Vincent 19914 SA 304 (SCA)

Putco v TAWUSA 201536 ILJ 2048 (LAC)

S v Matshili 19913 SA 264 (A)

SACCAWU v Sun International 20161 BLLR 97 (LC)

SACWU v Afrox 199920 ILJ 1718 (LC) 
SACTWU v Coats 200122 ILJ 1413 (LC)

TAWUSA obo members v Algoa Bus Company and Putco 201334 ILJ 2949 (LC)

TAWUSA v Putco 20166 BLLR 537 (CC)

Technikon SA v National Union of Technikon Employees of SA 200122 ILJ 427 (LAC)

\section{Legislation}

Constitution of the Republic of South Africa (Interim), 1993

Constitution of the Republic of South Africa, 1996

Labour Relations Act 28 of 1956

Labour Relations Act 66 of 1995

National Economic Development and Labour Council Act 35 of 1994

Railway Regulation Act of 1908

\section{Government publications}

Draft Labour Relations Bill of 1995

Explanatory Memorandum to the Labour Relations Bill (1995 16 ILJ 278)

GN 765 in GG 18887 of 15 May 1998

\section{International instruments}

ILO Right to Organise and Collective Bargaining Convention (No 98 of 1949)

\section{Internet sources}

Odendaal 2014 http://www.miningweekly.com/article/sa-one-of-the-worldsmost-violent-strike-prone-countries-2014-08-06

Odendaal N 2014 SA One of the World's Most Violent, Strike-prone Countries http://www.miningweekly.com/article/sa-one-of-the-worlds-mostviolent-strike-prone-countries-2014-08-06 accessed 10 September 2016 


\section{List of Abbreviations}

1956 LRA

ANC

Ann Surv SA L

CILSA

COBEO

\section{FAWU}

ILJ

ILO

Int'I J Labour Res

J Contemp Man

LDD

LRA

NEDLAC

SACTWU

SAJLR

SARPBAC

SACCAWU

SATAWU

TAWUSA

TOWU

U Pa L Rev
Labour Relations Act 28 of 1956

African National Congress

Annual Survey of South African Law

Comparative and International Law Journal of Southern Africa

Commuter Bus Employer's Organisation COBEO

Food and Allied Workers Union

Industrial Law Journal

International Labour Organisation

International Journal of Labour Research

Journal of Contemporary Management

Law Democracy and Development

Labour Relations Act 66 of 1995

National Economic Development and Labour Council

South African Clothing and Textile Workers' Union

South African Journal of Labour Relations

South African Rail Passenger Bargaining Council

South African Commercial, Catering and Allied Workers' Union

South African Transport and Allied Workers Union

Transport and Allied Workers Union of South Africa

Transport Omnibus Workers' Union

University of Pennsylvania Law Review 